\title{
Effects of fed mycotoxin contaminated diets supplemented with spray- dried porcine plasma on cholinergic response and behavior in piglets
}

\section{LUCIELI K.F. MÜLLER ${ }^{1}$, ALEKSANDRO S. DA SILVA ${ }^{1,2}$, NATHIELI B. BOTTARI ${ }^{2}$, JANIO M. SANTURIO ${ }^{3}$, VERA M. MORSCH ${ }^{2}$, MANOELA M. PIVA ${ }^{4}$, RICARDO E. MENDES ${ }^{4}$, EDUARDO M. GLORIA ${ }^{5}$ and DIOVANI PAIANO ${ }^{1}$}

\author{
${ }^{1}$ Programa de Pós-Graduação em Zootecnia, Universidade do Estado de Santa Catarina/UDESC, \\ Rua Beloni Trombeta Zanim, 680E, Santo Antônio, 89815-630 Chapecó, SC, Brazil \\ ${ }^{2}$ Programa de Pós-Graduação em Bioquímica Toxicológica, Departamento de Bioquímica e Biologia Molecular, \\ Universidade Federal de Santa Maria/UFSM, Avenida Roraima, 1000, 97105-900 Santa Maria, RS, Brazil \\ ${ }^{3}$ Departamento de Microbiologia e Parasitologia, Universidade Federal de Santa Maria/ \\ UFSM, Avenida Roraima, 1000, 97105-900 Santa Maria, RS, Brazil \\ ${ }^{4}$ Laboratório de Patologia Veterinária, Instituto Federal Catarinense/IFC, \\ Rodovia SC 283, s/n, 89703-720 Concórdia, SC, Brazil \\ ${ }^{5}$ Laboratório de Micologia, Universidade de São Paulo/USP, Avenida Dr. Enéas \\ Carvalho de Aguiar, 470, 05403-000 São Paulo, SP, Brazil
}

Manuscript received on April 27, 2018; accepted for publication on August 7, 2018

\begin{abstract}
How to cite: MÜLLER LKF, SILVA AS, BOTTARI NB, SANTURIO JM, MORSCH VM, PIVA MM, MENDES RE, GLORIA EM AND PAIANO D. 2019. Effects of fed mycotoxin contaminated diets supplemented with spray-dried porcine plasma on cholinergic response and behavior in piglets. An Acad Bras Cienc 91: e20180419. DOI 10.1590/0001-3765201920180419.
\end{abstract}

\begin{abstract}
The aim of this study was to evaluate the effect of spray-dried porcine plasma (SDPP) supplementation on cholinesterase enzymes and its relationship with animal behavior of weaning piglets exposed to mycotoxin contaminated diets. To achieve these objectives, two experimental design approaches were used. Male piglets $(7.15 \pm 0.61 \mathrm{~kg})$ were allocated in four groups: CTL group received a regular diet; SDPP group received a regular diet and 6\% SDPP; MYC group received a diet containing desired contamination of $210 \mu \mathrm{g} / \mathrm{kg}$ aflatoxins and $6.690 \mu \mathrm{g} / \mathrm{kg}$ fumonisins; group MYC+SDPP received $253 \mu \mathrm{g} /$ $\mathrm{kg}$ aflatoxins, $6930 \mu \mathrm{g} / \mathrm{kg}$ fumonisins and $6 \%$ SDPP. The animals treated with mycotoxin co-contaminated diets showed an increase in $\mathrm{AChE}$ and $\mathrm{BChE}$ activities in peripheral system (MYC) when compared to control (CTL). Furthermore, supplementation with SDPP (MYC+SDPP group) prevented the mycotoxinrelated reduction of $\mathrm{AChE}$ in blood and brain. Behavioral tests showed that sleeping and resting behaviors were more often observed in the MYC group; this group also fed fewer times when compared to the other groups, characterizing the deleterious effect of mycotoxins. Taken together, the data suggest changes in $\mathrm{AChE}$ and $\mathrm{BChE}$ activities may indicate alterations in cholinergic neurotransmission and consequently in the behavior of piglets.
\end{abstract}

Key words: mycotoxin, acetylcholinesterase, brain, spray-dried porcine plasma, animal health.

\footnotetext{
Correspondence to: Aleksandro Schafer da Silva

E-mail: aleksandro.silva@udesc.br

ORCid: https://orcid.org/0000-0002-9860-1933

Diovani Paiano

E-mail: diovani@hotmail.com

ORCid: https://orcid.org/0000-0003-2715-9524
} 


\section{INTRODUCTION}

Mycotoxins are considered important contaminants of maize-based products (Abdallah et al. 2015). The natural occurrence of aflatoxins, fumonisins, zearalenone, ochratoxin A, trichothecenes, patulin and penicillic acid is often observed in animal feed, and include the concomitant occurrence of two or more mycotoxins. These natural contaminants of cereals are found worldwide mainly in corn and its derived products.

Pigs are highly susceptible to aflatoxins and fumonisins, especially in the weaning stage where they may cause a variety of chronic or acute syndromes, depending on the level of consumption (Döll et al. 2003, Oswald et al. 2005). Studies have shown contamination of piglet feed with aflatoxins and fumonisins often results in poor performance, decrease in voluntary feed intake, weight loss and suppressed immune function. Other findings, including effects on the liver, alterations of serum biochemical parameters and gastrointestinal lesions, have also been reported (Dilkin et al. 2003).

Fumonisin toxicosis in swine is characterized by injury to the pulmonary, hepatic, cardiovascular and immune systems as well as early and widespread alterations of sphingolipid metabolism, growth rate and carcass composition (Haschek et al. 2001). As a consequence of the importance of these two mycotoxins for swine, the co-contamination of experimental diets with aflatoxins and fumonisins is important to simulate field situations.

Interestingly, the cholinergic system responds to various insults including oxidative stress, an important event that has been related to aflatoxicosis (Pohanka 2014). Acetylcholinesterase (AChE; EC 3.1.1.7) and butyrylcholinesterase (BuChE; EC 3.1.1.8) are two classes of cholinesterase enzymes involved incontrol of learning, memory, cortical organization of movement, immune responses, hydrolysis of esters of choline and xenobiotics (Soreq and Seidman 2001, Anglister et al. 2008).
Furthermore, studies have also demonstrated that mycotoxins can affect cholinergic enzymes suggesting that the higher the enzymatic activity the lower the cellular oxidative stress (Lautert et al. 2014).

Despite improvements in terms of detoxification and decontamination of animal feed, other strategies have been developed to supplement diets (Ferreira et al. 2009). Among the different processing methods, the spray-dried porcine plasma (SDPP) has been shown to be a good source of protein in the piglet diet (Butolo et al. 1999, Weaver et al. 2014). SDPP addition improves the digestibility and palatability of diets and has important nutritional characteristics due to the presence of immunoglobulins, low molecular weight proteins responsible for the immune response in the first two weeks of piglet life (Campbell et al. 2008, Gattás et al. 2008). Previous studies have shown that SDPP improves growth performance and reduces the inflammatory state when SDPP was used in piglet's diet (Pierce et al. 2005, Schuh et al. 2016). Importantly, SDPP use can be associated with minimum risk of pathogen transmission (Pujols et al. 2008, 2014) and the inclusion of $6 \%$ SDPP in the diets is economically viable for piglets (Müller et al. 2018a).

Kenney and Ganta (2014) demonstrated the interaction between nervous and immune systems. According to these authors, the central autonomic system is informed of peripheral immune status via several pathways, such as the production of cytokines. Cytokines alter the activity of sympathetic and parasympathetic nerves in lymphatic organs, and these alterations lead to a modulation of peripheral immune response by cholinergic anti-inflammatory pathway in immune cells. To our knowledge, there are no reports of the effects of SDPP on cholinergic pathway. Conversely, a few studies indicate the potential use of SDPP in the improvement of immune system (Nofrarías et al. 2007), including during mycotoxin intoxication 
(Müller et al. 2018b). Moreover, the antiinflammatory mechanism of action of SDPP was recently associated with reduction of lymphocyte activation (Pérez-Bosque et al. 2016), an immune cell that express cholinergic receptors in the plasma membrane. Thus, the aims of this study were to evaluate the effect of SDPP supplementation on cholinesterase enzymes and its relationship with animal behavior of weaning piglets exposed to diets contaminated with mycotoxins.

\section{MATERIALS AND METHODS}

\section{ETHICS COMMITTEE}

This experiment was approved by the Ethics Committee on Animal Research of University of Santa Catarina (UDESC), under protocol number 01.34.15.

\section{SPRAY-DRIED PORCINE PLASMA}

SDPP (AP 920®) was purchased from APC do Brasil Ltda (Campinas, São Paulo, Brazil). According to the manufacture, AP 920 should be added in the concentrations of 6 to $5 \%, 3$ to $2.5 \%$ and 1.5 to $1 \%$ in the initial, middle and final growth phase of piglets, respectively. In our study, based on the manufacturer's recommendation and on a previous published study (Weaver et al. 2014), we chose to use the concentration of $6 \%$ SDPP in the diets, given the mycotoxin challenge.

\section{MYCOTOXIN PRODUCTION}

The mycotoxin production method used in this study was previously detailed by Müller et al. (2017). Aflatoxins were produced by fermentation in converted rice under constant stirring and controlled temperature. The NRLL 2999 strain of Aspergillus parasiticus was used according to the method described by West et al. (1973). Ground rice was added to the feed as required, never exceeding $1 \%$ of the total diet. The autoclaved corn was inoculated with a Fusarium verticillioides strain and allowed to incubate at $25^{\circ} \mathrm{C}$ for 30 days. Thereafter, the corn was dried at $65{ }^{\circ} \mathrm{C}$ for $48 \mathrm{~h}$, milled and analyzed for fumonisins content.

Knowing the total levels of mycotoxins produced, i.e., $130 \mathrm{mg}$ of aflatoxins $/ \mathrm{kg}$ of rice and $110 \mathrm{mg}$ of fumonisins $/ \mathrm{kg}$ of corn. It was calculated the inclusion rate of contaminated material on the diet aiming to formulate the two experimental diets (MYC and MYC+SDPP) with desired levels of contamination, $300 \mu \mathrm{g} / \mathrm{kg}$ of aflatoxins and 8.000 $\mu \mathrm{g} / \mathrm{kg}$ fumonisins.

\section{QUANTIFICATION OF MYCOTOXINS IN DIETS}

The levels of aflatoxins and fumonisins in all diets were measured using high performance liquid chromatography technique, with imuno affinity purification, post column derivatization and fluorescence detection. The extraction and purification procedures was performed according to Aflatest WB and Fumonitest WB columns guide (VICAM Science Technology, Watertown, MA, USA). Post column derivatization for aflatoxins was obtained by a photo chemical reactor PHRED (Aura Industries Inc., NY, USA) and for fumonisins was used a chemical reaction procedure according to EN 16006 (European Committee for Standardization 2011). The methods presented a limit of quantification (LQ) of $0.5 \mu \mathrm{g} / \mathrm{kgfor}$ each aflatoxins (B1, B2, G1 and G2) and $100 \mu \mathrm{g} / \mathrm{kg}$ for fumonisin B1 and B2, respectively. Analysis of this diet showed that there was not a natural detectable contamination for aflatoxins (levels $<0.5 \mu \mathrm{g} / \mathrm{kg}$ ), but for fumonisin (B1 and B2) it was from 140 to $180 \mu \mathrm{g} / \mathrm{kg}$ (diets CTL and SDPP, respectively). The final level of contamination observed in the artificially contaminated diets (MYC and MYC+SDPP) were shown in Table I.

\section{ANIMALS}

Twenty-four castrated male piglets, from a commercial line, weighing $7.15 \pm 0.61 \mathrm{~kg}$ (24 
TABLE I

Ingredients of experimental diets. CTL: control diet; SDPP: control diet and SDPP; MYC: control diet and mycotoxins addition; MYC+SDPP: mycotoxins addition and SDPP.

\begin{tabular}{|c|c|c|c|c|}
\hline Ingredients (\%) & CTL & SDPP & MYC & $\mathrm{MYC}+\mathrm{SDPP}$ \\
\hline Corn & 39.43 & 46.33 & 33.23 & 40.11 \\
\hline Soybean meal & 31.38 & 20.25 & 30.43 & 19.31 \\
\hline Wheypowder & 15.0 & 15.0 & 15.0 & 15.0 \\
\hline Sugarcane & 5.0 & 5.0 & 5.0 & 5.0 \\
\hline Dicalciumphosphate & 1.29 & 1.23 & 1.30 & 1.24 \\
\hline Limestone & 0.74 & 0.82 & 0.74 & 0.84 \\
\hline Soybean oil & 3.40 & 2.11 & 3.35 & 2.08 \\
\hline Vitamin suplement ${ }^{1}$ & 0.30 & 0.30 & 0.30 & 0.30 \\
\hline Mineral suplement $t^{2}$ & 0.30 & 0.30 & 0.30 & 0.30 \\
\hline $\mathrm{ZnO}$ & 0.25 & 0.25 & 0.25 & 0.25 \\
\hline Salt & 0.37 & 0.04 & 0.37 & 0.04 \\
\hline L-Lysine $\mathrm{H}-\mathrm{Cl}$ & 0.84 & 0.75 & 0.86 & 0.78 \\
\hline DL-Methionine & 0.38 & 0.34 & 0.38 & 0.34 \\
\hline L-Threonine & 0.45 & 0.38 & 0.45 & 0.38 \\
\hline L-Tryptophan & 0.08 & 0.08 & 0.08 & 0.09 \\
\hline L-Isoleucine & 0.20 & 0.29 & 0.21 & 0.30 \\
\hline L-Valine & 0.58 & 0.52 & 0.59 & 0.52 \\
\hline Spray-dried porcine plasma & - & 6.0 & - & 6.0 \\
\hline Contaminant $1^{\#}$ & - & - & 0.23 & 0.23 \\
\hline Contaminant $2^{\&}$ & - & - & 6.91 & 6.88 \\
\hline
\end{tabular}

Exact mycotoxin levels in the diet

\begin{tabular}{lcccc}
\hline Aflatoxins $(\mathrm{B} 1+\mathrm{B} 2+\mathrm{G} 1+\mathrm{G} 2), \mu \mathrm{g} / \mathrm{kg}$ & $\mathrm{ND}^{*}$ & $\mathrm{ND}$ & 210 & 253 \\
Fumonisins $(\mathrm{B} 1+\mathrm{B} 2), \mu \mathrm{g} / \mathrm{kg}$ & 180 & 140 & 6690 & 6930 \\
\hline
\end{tabular}

*ND - Not Detected. ${ }^{*}$ Contaminant 1: Rice with $130 \mathrm{mg}$ of aflatoxins $/ \mathrm{kg}$. ${ }^{\&}$ Contaminant 2: Corn with $110 \mathrm{mg}$ of fumonisins $/ \mathrm{kg}$. ${ }^{1}$ Provided the following per kilogram of diet: Vit. A - 4,167.000 UI, Vit. D3 - 833.000 UI, Vit. E - 13,333 mg; Vit. K3 - 1.000 mg, Vit. B1 - $1.000 \mathrm{mg}$, Vit. B2 - $1.667 \mathrm{mg}$, Vit. B6 - $1.000 \mathrm{mg}$, Vit. B12 - $8 \mathrm{mg}$, Niacin - $11.667 \mathrm{mg}$, Pantothenic Acid - $7.333 \mathrm{mg}$; Folic acid - $200 \mathrm{mg}$; Colin - $104 \mathrm{mg}$; Biotin $-33 \mathrm{mg} ;{ }^{2} \mathrm{Ca}-(\mathrm{min} .166 \mathrm{~g}$ and max. $203 \mathrm{~g}$ ), Co - $266.7 \mathrm{mg}, \mathrm{Cu}-66.67 \mathrm{~g}, \mathrm{I}-600 \mathrm{mg}$, $\mathrm{Mn}-18.33 \mathrm{~g}$, Se $-135 \mathrm{mg}, \mathrm{Zn}-41.67 \mathrm{~g}$, Fe-66.67 g, $40 \mathrm{mg} / \mathrm{kg}$ growth promoter.

\pm 2 days) were used. The piglets were housed in pairs in $1.2 \times 0.5 \mathrm{~m}$ metal pens, with slatted polypropylene floor and with feed and water $a d$ libitum. The environment was heated by automatic electric heaters $\left(23 \pm 2{ }^{\circ} \mathrm{C}\right)$. The experiment was carried out in teaching facilities in the municipality of Chapecó, South of Brazil.

\section{TREATMENTS}

Four isonutritive diets were formulated according Rostagno et al. (2011) (i.e. all with calculated composition of $0.85 \%$ calcium, 0.43 phosphorus available, $0.28 \%$ sodium, $3.14 \mathrm{Mcal} / \mathrm{kg}$ metabolible energy, $21 \%$ crude protein, $1.65 \%$ lysine digestible, $0.91 \%$ methionine $+\mathrm{Cis}$ digestible, 
$0.30 \%$ tryptophan digestible, $1.11 \%$ threonine digestible, $1.37 \%$ valine digestible, and $0.91 \%$ isoleucine digestible), with corn and soy as the main ingredients of the diet (Table I). The chemical composition of the diets was made according to the recommended methodologies by Brasil (2005) and results showed in Table II.

The four diets represent the four treatments provided to the groups of post weaning animals, differing in contamination with aflatoxins and fumonisins in the addition or not of $6 \%$ of SDPP during 15 days of experiment. The animals were divided in four groups: CTL group, piglets fed with a control diet (without experimental contamination); SDPP group, piglets fed a control diet and SDPP 6\%; MYC group, piglets fed an experimental diet containing $210 \mu \mathrm{g} / \mathrm{kg}$ aflatoxins and $6.690 \mu \mathrm{g} /$ $\mathrm{kg}$ fumonisins; and MYC+SDPP group, piglets fed an experimental diet containing $253 \mu \mathrm{g} / \mathrm{kg}$ of aflatoxins, $6.930 \mu \mathrm{g} / \mathrm{kg}$ fumonisins and $6 \%$ SDPP. The concentrations of aflatoxins and fumonisins used in this study were based on a study conducted by Drabek et al. (1989) and Weaver et al. (2014), respectively, that concluded that this concentration reduces the performance of pigs and the biological value of their meat. The concentration of SDPP was based on a study conducted by Weaver et al. (2014).

\section{SAMPLE COLLECTION AND PREPARATION}

Blood was collected at days 5, 10 and 15 of experiment by vena cava puncture in vaccutainer tubes using EDTA as anticoagulant. The samples were hemolyzed with phosphate buffer, $\mathrm{pH} 7.4$, and containing $0.03 \%$ Triton $\mathrm{X} 100$ and stored at $-20{ }^{\circ} \mathrm{C}$ for one week until AChE analysis. Serum was obtained from whole blood collected in tubes without anticoagulant and centrifuged at $3.000 \mathrm{rpm}$ for $15 \mathrm{~min}$. Samples were stored at $-20^{\circ} \mathrm{C}$ until use.

At day 15 of experiment, five animals per group were euthanized. Fragments of liver, intestine (duodenum, jejunum and ileum) and brain
TABLE II

Chemistry composition of experimental diets with mycotoxin (MYC) and spray-dried porcine plasma (SDPP).

\begin{tabular}{lcccc}
\hline $\begin{array}{c}\text { Chemistry } \\
\text { composition } \\
(\%)\end{array}$ & CTL & SDPP & MYC & MYC+SDPP \\
\hline Drymatter & 91.90 & 91.75 & 92.51 & 91.89 \\
Ash & 5.38 & 4.90 & 5.94 & 5.16 \\
Crude Protein & 20.15 & 20.43 & 21.11 & 21.42 \\
$\begin{array}{l}\text { Acid } \\
\text { detergente }\end{array}$ & 2.02 & 1.63 & 1.55 & 1.85 \\
fiber & & & & \\
\hline
\end{tabular}

Note: CTL group: control diet; SDPP group: control diet and $6 \%$ of SDPP; MYC group: $210 \mu \mathrm{g} / \mathrm{kg}$ aflatoxins and 6.690 $\mu \mathrm{g} / \mathrm{kg}$ fumonisins; MYC+SDPP group: $253 \mu \mathrm{g} / \mathrm{kg}$ aflatoxins, $6.930 \mu \mathrm{g} / \mathrm{kg}$ of fumonisins and $6 \%$ SDPP.

were removed and kept in 10\% formalin buffer for histopathological analysis. Cerebral cortex and cerebellum were segregated and placed in a solution of $10 \mathrm{mM}$ Tris-HCl, pH 7.4 on ice. Brain structures were homogenized in a glass potter in Tris- $\mathrm{HCl}$ solution. Aliquots of resulting brain structure homogenates were stored at $-20{ }^{\circ} \mathrm{C}$ until use. Protein was determined previously in a strip that varied for each structure: cerebral cortex $(2 \mathrm{mg}$ / $\mathrm{mL})$ and cerebellum $(2 \mathrm{mg} / \mathrm{mL})$ as determined by the Coomassie blue method according to Bradford (1976), using bovine serum albumin as standard solution.

\section{ACETYLCHOLINESTERASE ACTIVITY}

Cerebral AChE activity was determined by Rocha et al. (1993), with modification. The reaction mixture $(300 \mu \mathrm{L}$ final volume) contained 100 $\mathrm{mM} \mathrm{K+-phosphate} \mathrm{buffer,} \mathrm{pH} 7.5$ and $1 \mathrm{mM}$ 5.5'-dithiobisnitrobenzoic acid (DTNB). The enzyme ( $2 \mathrm{mg}$ of protein) was pre-incubated at $25{ }^{\circ} \mathrm{C}$ with $0.8 \mathrm{mM}$ acetylthiocholine iodide (AcSCh) as substrate for $2 \mathrm{~min}$. The formation of the 5.5'-dithio-bis-acid-nitrobenzoic anion was measured spectrophotometrically by absorbance 
at $412 \mathrm{~nm}$. The results were expressed in $\mu \mathrm{mol}$ $\mathrm{AcSCh} / \mathrm{h} / \mathrm{mg}$ of protein.

The specific activity of whole blood AChE was determined according to Worek et al. (1999). AChE activity was calculated from the quotient between AChE activity and hemoglobin content and the results were expressed as $\mathrm{mU} / \mu \mathrm{mol}$ of whole blood.

\section{BUTYRYLCHOLINESTERASE}

BuChE activity was determined in serum by Ellman et al. (1961), with modification. The reaction mixture $(300 \mu \mathrm{L})$ contained $100 \mathrm{mM}$ potassium phosphate buffer, $\mathrm{pH} 7.5$, and $1 \mathrm{mM}$ DTNB. The method is based on the formation of the yellow anion, 5.5'-dithio-bis-acid nitrobenzoic, measured by absorbance at $412 \mathrm{~nm}$ after 2 min incubation at $25{ }^{\circ} \mathrm{C}$. Enzyme activity was expressed in $\mu \mathrm{mol}$ $\mathrm{BuSCh} / \mathrm{h} / \mathrm{mg}$ of protein.

\section{HISTOPATHOLOGY}

Sagittal sections ( $3 \mathrm{~mm}$ thick) of the liver, intestine and brain were mounted and fixed in 10\% buffered formalin solution. Slides were stained with hematoxylin and eosin (H\&E) for histopathological analysis.

\section{BEHAVIORAL PROCEDURE}

The behavioral test was carried out in two moments. The first one was based on the use of the 0-1 (zero-one) method adapted from Castro (2010), where observations were made of the postfeeding period on the last day of each stage, i.e., on days 5, 10 and 15 after diet supplementation. Animals had free access to feed, except for the behavioral tests when the ration was offered at 10 different moments of each evaluated day, i.e., for five minutes immediately after feeding (totaling 50 min of observations per day). The first evaluation occurred at 07:00 AM and the last at 07:00 PM of each day (eight other evaluations occurred between these periods). When the expected behavior was visualized (the same observer was used throughout the experiment), it was recorded as " 1 " and when it was not observed at that time it was recorded as " 0 " (zero). In the echogram, the behaviors were classified as resting (resting or sleeping), eating or other behavior (playing or walking). These data were later tabulated and transformed to numbers for subsequent statistical analysis. It is important to note that a mean of behaviors of each piglet of the 10 moments of each day was made, and therefore only one data for each animal per day was tabulated for statistical analysis.

The second behavioral analysis was conducted on day 15 of experiment. A new objected was insertedin the pens to determine the behavior of each piglet to a novelty in the environment, following the method adapted by Cramer (2014). Metal chains measuring $25 \mathrm{~cm}$ in length were attached to the top of the cage, hanging at the height of the pigs, which allowed the chain to have one side free to be moved according to the interaction of the animal. This interaction was recorded during 30 minutes (10:00 to 10:30 AM) using a digital camera on day 15 of experiment. To distinguish the two animals from each cage, these were identified with nontoxic paint markers in the back. The length of time each animal took to make the first contact with the new object and the length of time that the animal remained interacting with it was registered.

\section{STATISTICAL ANALYSIS}

Data were first analyzed by descriptive statistics for contingency of the information and for further assumptions, and were presented as descriptive (mean and standard deviation). The data were tested for normality of variance by the KolmogorovSmirnov test, skewness and homogeneity by the Levene test, and did not show normal distribution. Therefore, data were transformed to logarithm and submitted first to one-way analysis of variance (ANOVA) followed by the Duncan test to verify 
differences among groups in the three moments separately. Results of serum AChE and BChE activities were submitted to repeated measures one-way ANOVA to analyze if these parameters showed significant differences over time. Groups of the experiment II were compared considering the three evaluated moments (days 5, 10 and 15 of experiment). Data were considered significantly different when $\mathrm{P}<0.05$. The statistical analysis was carried out with R-language, v.3.3.0, 2012 (R Development Core Team).

\section{RESULTS}

\section{CLINICAL SIGNS AND HISTOPATHOLOGICAL ANALYSES}

No apparent clinical signs were observed in the piglets that received mycotoxins in the diet, suggesting absence of clinical intoxication. No histopathological lesions were observed in the liver, intestine or brain in the piglets of this experiment.

\section{AChE ACTIVITIES}

AChE activity in whole blood did not show significant differences among the groups at day 5 of experiment (Fig. 1). At day 10, AChE activity significantly increased in MYC (50\%) group when compared to CTL and MYC+SDPP (65\%) groups $(\mathrm{P}<0.05)$. However, at day 15 of experiment, whole blood AChE activity was significantly decreased in MYC 100\% compared to control, 65\% compared to SDPP and increase $75 \% \mathrm{MYC}+\mathrm{SDPP}$ compared to MYC group. In cerebral cortex, AChE activity was significantly affected in MYC group when compared to other treatments (CTL (decrease 15\%), SDPP (decrease 35\%) and MYC+SDPP (increase $25 \%)$ ). The treatments did not affect AChE activity in cerebellum $(\mathrm{P}<0.05)$.

A significant increase on blood $\mathrm{AChE}$ activity was observed from day 5 from $10(\mathrm{P}=0.04 ; \mathrm{P}<0.001)$ in the SDPP and MYC groups. Conversely, a reduction on AChE activity was observed from
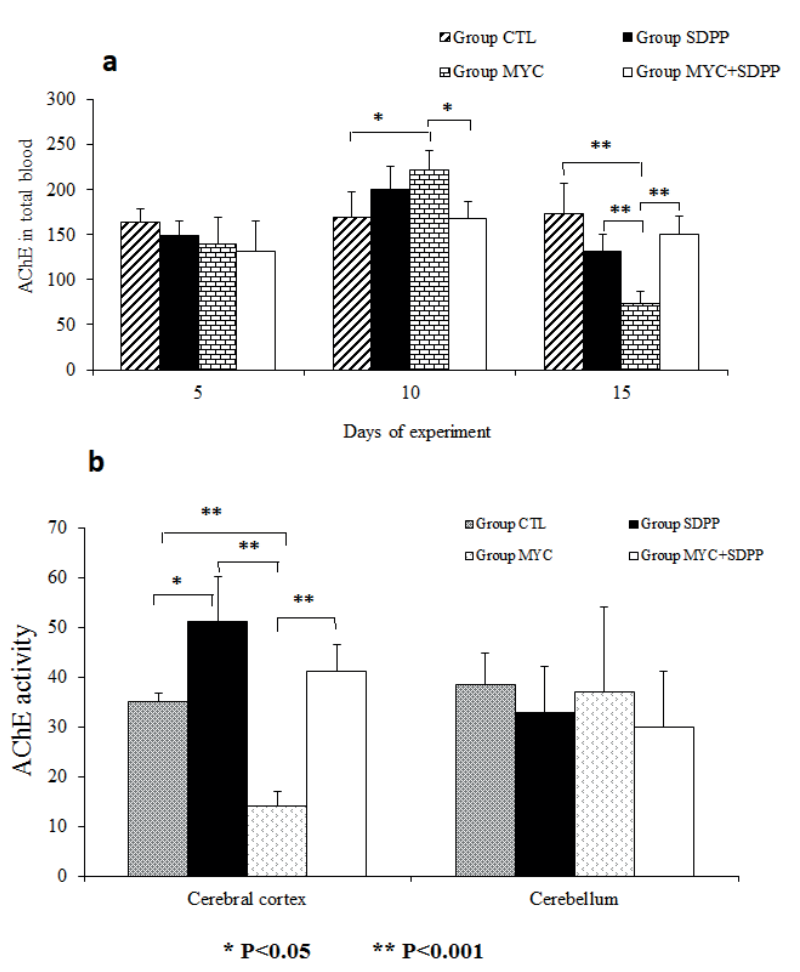

Figure 1 - AChE activity in whole blood (mU AcSCh/umolHb), cerebral cortex and cerebellum ( $\mu \mathrm{mol} \mathrm{AcSCh} / \mathrm{h} / \mathrm{mg}$ protein) of piglets treated with mycotoxins and spray-dried porcine plasma (SDPP) (Experiment I). CTL group: control diet; SDPP group: control diet and 6\% of SDPP; MYC group: 210 $\mu \mathrm{g} / \mathrm{kg}$ aflatoxins and $6.690 \mu \mathrm{g} / \mathrm{kg}$ fumonisins; MYC+SDPP group: $253 \mu \mathrm{g} / \mathrm{kg}$ aflatoxins, $6.930 \mu \mathrm{g} / \mathrm{kg}$ of fumonisins and $6 \%$ SDPP. Bars represent means \pm standard deviation. Comparison among the four groups, in each separate period of the experiment or brain structure (ANOVA followed by the Duncan test). One asterisk $(*)$ or two asterisk $(* *)$ illustrates the difference between groups in the probability of $<0.05$ and $<0.001$, respectively.

day 5 from $15(\mathrm{P}<0.001)$ and from day 10 from 15 $(\mathrm{P}<0.001)$ in the MYC group.

\section{BChE ACTIVITIES}

At day 5 of experiment, serum BChE activity did not differ among the groups (Fig. 2). At days 10 and 15 of experiment, BChE activity increased in piglets that received diets containing mycotoxins (MYC group) when compared to control (CTL $(100 \%)$ and SDPP (75\%) at 10 days) (CTL (75\%) and SDPP $(35 \%)$ at 15 days $)(\mathrm{P}<0.05)$. The SDPP supplementation associated to mycotoxin 


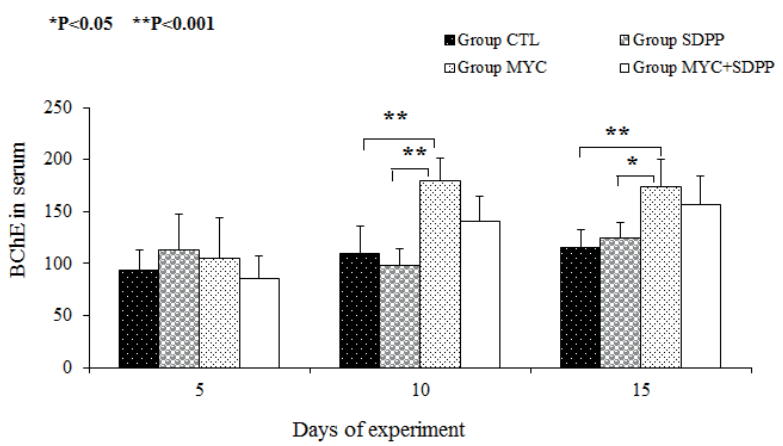

Figure 2 - Effect of mycotoxins and spray-dried porcine plasma (SDPP) on BChE activity in serum $(\mu \mathrm{mol} \mathrm{BuSCh} / \mathrm{h} /$ $\mathrm{mg}$ of protein) of piglets (Experiment I). CTL group: control diet; SDPP group: control diet and supplementation with $6 \%$ of SDPP; MYC group: $210 \mu \mathrm{g} / \mathrm{kg}$ aflatoxins and $6.690 \mu \mathrm{g} / \mathrm{kg}$ fumonisins; MYC+SDPP group: $253 \mu \mathrm{g} / \mathrm{kg}$ aflatoxins, 6.930 $\mu \mathrm{g} / \mathrm{kg}$ of fumonisins and $6 \%$ SDPP. Bars represent means \pm standard deviation. *Comparison among the four groups, in each separate period of the experiment (ANOVA followed by the Duncan test). One asterisk (*) or two asterisk (**) illustrates the difference between groups in the probability of $<0.05$ and $<0.001$, respectively.

(MYC+SDPP group) did not show significant difference when compared to MYC group.

In the MYC group, a significant increase on $\mathrm{BChE}$ activity in serum was observed from day 5 from $10(\mathrm{P}=0.02)$ and from day 5 from $15(\mathrm{P}=0.05)$. An increase in $\mathrm{BChE}$ also was observed from day 5 from 15 of experiment in the MYC+SDPP group.

\section{BEHAVIORAL TESTS}

The behavioral results are shown in Fig. 3. The animals that received mycotoxins in the diet (MYC group) spent most of the time sleeping. Moreover, the resting behavior of MYC group was statistically increased when compared to the other groups and, conversely, the feeding behavior was decreased $(\mathrm{P}<0.05)$ when compared to CTL and SDPP groups. Animals that received SDPP (MYC+SDPP group) showed similar behavior patterns to animals of CTL and SDPP groups $(\mathrm{P}>0.05)$. No statistical difference was observed among the groups in the test of interaction with objects $(\mathrm{P}>0.05)$.

In summary, the number of times of active behaviors of MYC group was decreased when

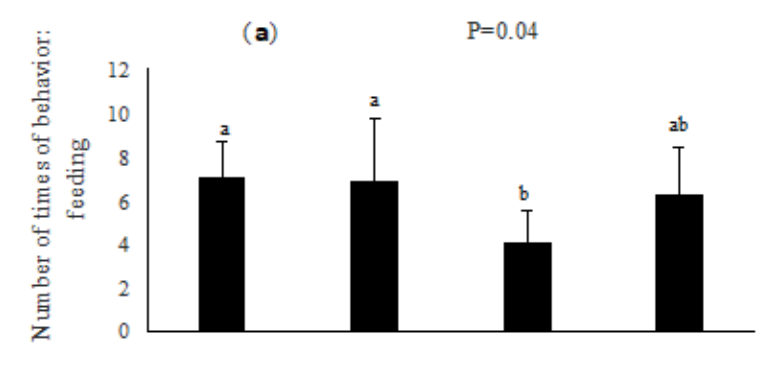

(b) $\quad \mathrm{P}>0.05$
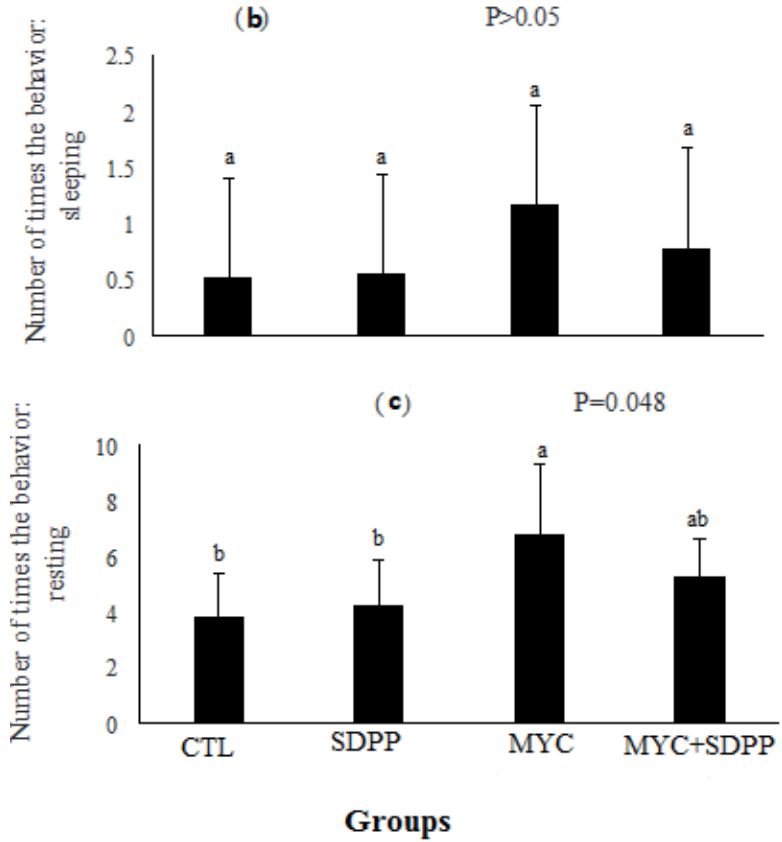

Figure 3 - Effect of mycotoxins and spray-dried porcine plasma (SDPP) on the behavior (Y-axis) evaluated on days 5, 10 and 15 of experiment to number of behavior: feeding (a), sleeping (b) and resting (c). CTL group: control diet; SDPP group: control diet and 6\% of SDPP; MYC group: $210 \mu \mathrm{g} / \mathrm{kg}$ aflatoxins and $6.690 \mu \mathrm{g} / \mathrm{kg}$ fumonisins; MYC+SDPP group: $253 \mu \mathrm{g} / \mathrm{kg}$ aflatoxins, $6.930 \mu \mathrm{g} / \mathrm{kg}$ of fumonisins and $6 \%$ SDPP. Results show mean and standard deviation. Groups with equal letters $(a, b)$ in the same graph do not differ statistically from each other $(\mathrm{P}>0.05)$.

compared to the others (CTL group: 15.1, SDPP group: 15.2, MYC group: 11.9, and MYC+SDPP group: 14.5). Nonetheless, the number of times of resting behavior was increased in animals of MYC group (CTL group A: 4.8, SDPP group: 4.7, MYC group: 7.6, and MYC+SDPP group: 5.8).

\section{DISCUSSION}

SDPP is an excellent source of proteins for newborn piglets due to great amino acid ratio and 
high level of globular proteins that stimulate the feed intake and performance during the critical post weaning phase (Cromwell 2006). In the present study, SDPP supplementation showed beneficial effects on behavior of piglets exposed to mycotoxin co-contamination food. In a previous study with these animals published by Muller et al. (2018a) it was observed that the animals that received SDPP had greater weight gain and a lower incidence of diarrhea in a diet with low and high mycotoxin, another positive effect of supplementation.

The ingestion of diets containing mycotoxins resulted in a decrease of feed-intake behavior of animals and an increased frequency of sleeping and resting behaviors. These results are in agreement with Pierce et al. (2005) which verified that mycotoxin intoxication in pigs decrease voluntary feed intake. Due to the limited digestive capacity of piglets, the addition of SDPP in the post weaning increases the locomotion and improves active behavior of animals. Touchette et al. (1996) have associated a stimulatory plasma effect with the ingestion and maintenance of intestinal villi in piglets, which may have occurred due to the action of plasma or to the stimulus it exerts on food consumption.

SDPP supplementation increased AChE activity in cerebral cortex of piglets. The lack of uniformity in the AChE profile may be a reflection of the functional heterogeneity in the central cholinergic system. Cerebellum presents few cholinergic neurons, which is likely to explain the low AChE activity (Das et al. 2001). Our findings indicate that mycotoxins increased whole blood $\mathrm{AChE}$ and serum $\mathrm{BChE}$ activities of piglets throughout the experiment. This activation leads to fast acetylcholine degradation, as observed at day 15 of experiment, and a subsequent downstimulation of acetylcholine receptors causing undesirable effects on locomotion functions (Soreq and Seidman 2001). Furthermore, based on these results, it is suggested that the mycotoxin-related increase in BChE activity decreases butyrylcholine efficiency in the synaptic cleft and serum, thus contributing to regressive behavior.

The use of SDPP of pig origin has demonstrated better results when compared to that of bovine origin, suggesting a specific effect of immunoglobulin (Dalto et al. 2013). Furthermore, the beneficial effect of SDPP is related to the high levels of IgG that remain active in the manufactured plasma (Pierce et al. 2005, Campbell et al. 2008). AChE is an enzyme present in the central nervous system and lymphocytic membrane that is responsible for regulating acetylcholine, which modulates the activation and differentiation of lymphocytes improving immune response (Wessler and Kirkpatrick 2001).

SDPP supplementation was able to avoid the changes in whole blood AChE activity at days 10 and 15 of exposition to mycotoxins in feed. The data suggest that SDPP can decrease free acetylcholine in order to minimize and/or modulate inflammation caused by aflatoxins and fumonisins throughout the experiment. The increase of AChE in cerebral cortex was observed at the end of the experiment. The addition of SDPP avoided mycotoxin-related changes in BChE activity. Thus, SDPP treatment can be contributing to a greater absorption of immunoglobulins and, consequently to increase the passive immunity of piglets.

The results of this experiment can contribute to the potential production and quality of the animal diet, since the presence of mycotoxin can affect cholinergic system causing less response to food intake, limited locomotion and development of immature piglets. On the other hand, the supplementation with SDPP is an excellent source of proteins for newborns, improving the nutrient recovery, reducing the overstimulation of the immune response, and preserving the use of nutrients for better productive performance. 


\section{CONCLUSION}

In summary, the present study showed that the co-contamination of aflatoxins and fumonisins to piglet diets avoids the increase and reduction of seric $\mathrm{AChE}$ and $\mathrm{BChE}$ activities, respectively. Subclinical mycotoxin poisoning in piglets (MYC group) reduces the activity of cerebral AChE, thus interfering in the hydrolysis of the neurotransmitter acetylcholine in the synaptic cleft and, consequently, altering the behavior of the animals. The SDPP supplementation avoids changes in blood and brain AChE activity in animals exposed to mycotoxin co-contaminated diets, directly or indirectly, by unknown mechanisms.

\section{ACKNOWLEDGMENTS}

We would like to thank Ajinomoto do Brasil (Nutract Alimentos and Vitamix Nutrição Animal) for supplying some of the ingredients used in the present study. We also thank the people who positively contributed with this project: Jeferson Gugel, William Raphael Lorenzetti and Régis Adriel Zanette.

\section{AUTHOR CONTRIBUTIONS}

Müller, Da Silva and Paiano planned the experiment and performed; Bottari, Morsch, Piva and Mendes participated in the laboratory analysis. Santurio and Gloria participated in the idealization of the project and production of mycotoxins. All authors participated in the discussion of the results and writing of the manuscript.

\section{REFERENCES}

ABDALLAH MF, GIRGIN G AND BAYDAR T. 2015. Ocurrence, prevention and limitation of mycotoxins in feeds. An Nutr Feed Techonol 15: 471-490.

ANGLISTER L, ETLIN A, FINKEL E, DURRANT A AND LEV-TOV A. 2008. Cholinesterases in development and disease. Chem Biol Interact 175: 92-100.

BRADFORD MM. 1976. A rapid and sensitive method for the quantitation of microgram quantities of protein utilizing the principle of protein-dye binding. Anal Biochem 72 : 248-254.

BRASIL. 2005. Ministério da Agricultura e Abastecimento. Sindicado Nacional da Industria e Alimentação Animal. Associação Nacional dos Fabricantes de Ração. Compendio Brasileiro de Alimentação Animal. São Paulo: ANFAR/CBNA/SDR.

BUTOLO EAF, MIYADA VS, PACKER IU AND MENTEN JFM. 1999. The use of Spray-Dried Porcine Plasma in early-weaned pig diets. Rev Bras Zootec 28: 326-333.

CAMPBELL J, CRENSAHW J, RUSSELL L, HAYES S, BARANCELLI GV AND RANGEL LFS. 2008. Uso do plasma para modular a resposta inflamatória e o seu impacto na produção de suínos. Acta Sci Vet 36: 53-59.

CASTRO CSS. 2010. Pesquisa com primatas em ambiente natural: técnicas para coleta de dados ecológicos e comportamentais. R Soc Bras Prog Ciênc 62: 1-27.

CEN - EUROPEAN COMMITTEE FOR STANDARDIZATION. 2011. CEN EN 16006 - Animal feeding stuffs - Determination of the Sum of fumonisin $\mathrm{B} 1$ and $\mathrm{B} 2$ in compound animal feed with immune affinity clean-up and RP-HPLC with fluorescence detection after pre- or postcolumn derivatisation. European Committee for Standardization, Brussels, Belgium.

CRAMER MC AND STANTON AL. 2015. Associations between health status and the probability of approaching a novel object or stationary human in preweaned grouphoused dairy calves. J Dairy Sci 98: 7298-7308.

CROMWELL GL. 2006. Rendered products in swine nutrition. Essential rendering-National Renderers Association. Kirby, Airlington, p. 141-157.

DALTO DB, GAVIOLI DF, OLIVEIRA ER, DA SILVA RAM AND TARSITANO MA. 2013. Efeito de dietas contendo plasma sanguíneo desidratado sobre características microbiológicas, imunológicas e histológicas de leitões leves ao desmame. Arq Bras Med Vet Zootec 65: 189-197.

DAS A, DIKSHIT M AND NATH C. 2001. Profile of acetylcholinesterase in brain areas of maleand female rats of adult and old age. Life Sci 68: 1545-1555.

DILKIN P, ZORZETE P, MALLMANN CA, GOMES JDF AND UTIYAM CE. 2003. Toxicological effects of chronic low doses of aflatoxin B1 and fumonisin B1-containing Fusarium moniliforme culture material in weaned piglets. Food Chem Toxicol 41: 1345-1353.

DÖLL S, DÄNICKE S, UEBERSCHÄR KH, VALENTA H AND SCHNURRBUSCH U. 2003. Effects of graded levels of Fusarium toxin contaminated maize in diets for female weaned piglets. Arch Anim Nutr 57: 311-334.

DRABEK J, MIKULIK A, PISKAC A, RUPRICH J AND HAOUZKA R. 1989. The effect of aflatoxins on growth in pigs and the biological value of the meat. Vet Med 34: 223-229.

ELLMAN GL, COURTNEY DK, ANDRES V AND FEATHERSTONE RM. 1961. Anew and rapid colorimetric determination of acetylcholinesterase activity. Biochem Pharmacol 7: 88-95. 
FERREIRA AS, BARBOSA FF, TOKACH MD AND SANTOS M. 2009. Spray dried plasma for pigs weaned at different ages. R Pat Food Nutr Agr 1: 231-235.

GATTÁS G, FERREIRA AS, BARBOSA FF, SILVA FCO, DONZELE JL AND LOPES DC. 2008. Plasma sanguíneo em pó em dietas para leitões desmamados aos 14 dias de idade. Rev Bras Zootec 37: 278-285.

HASCHEK WM, GUMPRECHT LA, SMITH G, TUMBLESON ME AND CONSTABLE PD. 2001. Fumonisin toxicosis in swine: an overview of porcine pulmonary edema and current perspectives. Environ Health Persp 109: 251-257.

KENNEY MJ AND GANTA CK. 2014. Autonomic nervous system and immune system interactions. Comp Physiol $4: 1177-1200$.

LAUTERT C, FERREIRO L, WOLKMER P, PAIM FC, DA SILVA CB, JAQUES JA, LOPES ST AND SANTURIO JM. 2014. Individual in vitro effects of ochratoxin A, deoxynivalenol and zearalenone on oxidative stress and acetylcholinesterase in lymphocytes of broiler chickens. Springer Plus 3: 506.

MÜLLER LKF ET AL. 2018b. Spray-dried porcine plasma added to diets contaminated with aflatoxins and fumonisins shows beneficial effects to piglet health. An Acad Bras Ciênc 90: 3115-3128.

MÜLLER LKF, PAIANO D, GUGEL J, LORENZETTI WR, SANTURIO JM, TAVERNARI FC, GLORIA EM, BALDISSERA MD AND SILVA AS. 2018a. Post-weaning piglets fed with different levels of fungal mycotoxins and spray-dried porcine plasma have improved weight gain, feed intake and reduced diarrhea incidence. Microb Pathog 117: 259-264.

MÜLLER LKF, SILVA AS, BALDISSERA MD, SANTURIO JM, GLOMBOWSKY P, GUGEL J, CAMPIGOTTO G, GLORIA EM, PAIANO D AND MACHADO G. 2017. Effects of supplementation with spray-dried porcine plasma on blood variables on piglets feed with diet contaminated by mycotoxins. Microb Pathog 110: 464-470.

NOFRARÍAS M, MANZANILLA EG, PUJOLS J, GIBERT X, MAJÓ N, SEGALÉS J AND GASA J. 2007. Spraydried porcine plasma affects intestinal morphology and immune cells subsets of weaned pigs. Livest Sci 108: 299302.

OSWALD IP, MARIN DE, BOUHET S, PINTON P, TARANU I AND ACCENSI F. 2005. Immunotoxicological risk of mycotoxins for domestic animals. Food Additi Contam 22: 354-360.

PÉREZ-BOSQUE A, POLO J AND TORRALLARDONA D. 2016. Spray dried plasma as an alternative to antibiotics in piglet feeds, mode of action and biosafety. Porcine Health Management 2: 16.

PIERCE JL, CROMWELL GL, LINDEMANN MD, RUSSELL LE AND WEAVER EM. 2005. Effects of spray-dried animal plasma and immunoglobulins on performance of early weaned pigs. J Anim Sci 83: 28762885.

POHANKA M. 2014. Inhibitors of Acetylcholinesterase and butyrylcholinesterase Meet Immunity. Int J Mol Sci 15: 9809-9825.

PUJOLS J ET AL. 2008. Lack of transmission of porcine circovirus type 2 to weanling pigs by feeding them spraydried porcine plasma. Vet Record 163: 536-538.

PUJOLS J, RODRÍGUEZ C, NAVARRO N, PINA-PEDRERO S, CAMPBELL JM, CRENSHAW J AND POLO J. 2014. No transmission of hepatitis $E$ virus in pigs fed diets containing commercial spray-dried porcine plasma: a retrospective study of samples from several swine trials. Virol J 11: e232.

ROCHA JBT, EMANUELLI T AND PEREIRA ME. 1993. Effects of early undernutrition on kinetic parameters of brain acetylcholinesterase from adult rats. Acta Neurobiol Exp 53: 431-437.

ROSTAGNO HS, ALBINO LFT, DONZELE JL, GOMES PC, OLIVEIRA RF, LOPES DC, FERREIRA AS, BARRETO SLT AND EUCLIDES RF. 2011. Composição de alimentos e exigências nutricionais. Tabelas brasileiras para aves e suínos. Viçosa, Minas Gerais: Universidade Federal de Viçosa, Brasil.

SCHUH S, MULLER LKF, CAMPOS LP, MORESCO RN AND BALDISSERA MD. 2016. Effect of supplementation of newborn piglets with spray dry blood plasma on weight gain and serum biochemical variables. Comp Clin Pathol 25: 1029-1033.

SOREQ H AND SEIDMAN S. 2001. Acetylcholinesterase — new roles for an old actor. Nature Rev Neurosci 2: 294 302.

TOUCHETTE KJ, ALLEE GL AND NEWCOMB MD. 1996. The effects of plasma, lactose, and soy protein source fed in a phase I diet on nursery performance. J Anim Sci 74(Suppl. 1): 170.

WEAVER AC, CAMPBELL JM, CRENSHAW JD, POLO J AND KIM W. 2014. Efficacy of dietary spray dried plasma protein to mitigate the negative effects on performance of pigs fed diets with corn naturally contaminated with multiple mycotoxins. J Anim Sci 92: 3878-3886.

WESSLER I AND KIRKPATRICK CJ. 2001. Role of nonneuronal and neuronal acetylcholinein the airways. In: Zaagsma J, Meurs H and Roffel AF (Eds), Muscarinic receptors in airways diseases. Birkhäuser, Basel, p. 25-62.

WEST S, WYATT RD AND HAMILTON PB. 1973. Improved Yield of Aflatoxin by Incremental Increases of Temperature. Appl Environ Microbiol 25: 1018-1019.

WOREK F, MAST U, KIDERLEN D, DIEPOLD C AND EYER P. 1999. Improved determination of acetylcholinestrase activity in human whole blood. Clin Chim Acta 288: 73-79. 